\title{
Dijital Çağda Yükseköğretimde Öğretimin Yönetimine İlişkin Meta-Analitik Bir Çözümleme ${ }^{1}$
}

\author{
DOI: 10.26466/opus.627050
}

*

\author{
Aydın Aslan $^{*}$ - Kamil Yıldırım ${ }^{* *}$ \\ * Dr, Öğr. Üyesi, Selçuk Üniversitesi, Eğitim Fakültesi Selçuklu / Konya/ Türkiye \\ E-Posta: aydin.aslan@selcuk.edu.tr \\ ORCID: $\frac{0000-0001-6173-5367}{2}$ \\ ** Dr. Öğr. Üyesi, Aksaray Üniversitesi, Eğitim Fakültesi, Aksaray / Türkiye \\ E-Posta: kamilyildirim1@gmail.com \\ ORCID: $\underline{0000-0002-5212-3905}$
}

Öz

Bu çalışmada, dijital çă̆ın firsatları dikkate alınarak yükseköğretim düzeyinde öğretimin nasıl daha etkili gerçekleştirildiğine iliş̧kin ulaşılan çalışmalar araştırılmıştır. Etkili bir öğretimin gerçekleştirilmesinde öğretimin yönetimi önemli bir rol oynamaktadır. Öğretimin yönetimini yükseköğretime nasıl uygulanacağı belirlemek için Thomson-Reuters Web of Science, Academic Search Complete, ProQuest, OECD iLibrary, Ebook Central ve Ulakbim Sosyal Bilimler Veri Tabanı arama motorlarında"yönetim süreçleri-management process", "öğretim/yetiştirme-instuction/teaching" ve "dijital-digital" anahtar kelimeleriaranmıştır. Doküman arama süreci sonundason beş yılda yayınlanmış kitap, tez ve makale türünde toplam 195 doküman araştırmanın evrenini oluşturmuştur. Amaçlı, tabakalı ve tesadüfi örnekleme ile 49 doküman incelenmiştir. Dokümanlarn incelemek için planlama, organizasyon, başlatma-sürdürme ve denetim boyutların içeren yönetim süreçleri ile altı ögrretimsel ögenin birleşimiyle oluşturulan bir matris kullanılmıştır. Böylece içerik analiziyle elde edilen bulgular analitik yolla tasnif edilmiş ve toplam 59 tema altında 566 bilgi parçası saptanmıştır. Çalışma sonucunda bilgi parçalartnın en sıklikla başlatma-sürdürme sürecinde ve model, strateji, yöntem ve teknik öğretimsel ögesinde yer aldığı saptanmıştır. Sonuçlar tartışılarak uygulamada kullanılabilecek öneriler geliştirilmiştir.

Anahtar Kelimeler: Öğretimin yönetimi, yükseköğretim, öğretimsel öge, yönetim süreçleri

\footnotetext{
${ }^{1}$ 4-6 Ekim 2019 tarihlerinde arasında düzenlenen Ankara Uluslararası Araştırmalar Kongresinde sözlü bildiri olarak sunulmuştur.
} 


\title{
Meta-analytic Analysis Concerning Instruction Management in Higher Education in Digital Age
}

\begin{abstract}
In this study, more effective instruction was investigated to be implemented in higher education taking into account the opportunities of the digital age. Instruction management plays a significant role in conducting an effective instruction. To identify how to implement instruction management in higher education, "management process, instruction/teaching and digital" key words were searched in Thomson-Reuters Web of Science, Academic Search Complete, ProQuest, OECD iLibrary, Ebook Central and Ulakbim Social Sciences search engines. As a result of document review, a total of 195 documents identified in books, theses and articles in the past five years constituted the population of the research. 49 documents were examined through purposeful, stratified and random sampling. A matrix was created to examine the documents with regard to management processes consisting of planning, organization, implementation and controlling dimensions and six instructional elements. The findings derived from the content analysis were analytically classified and 566 instructional elements under 59 themes were determined. As a result of the study, it was found that the most frequently mentioned findingsare implementation and model, strategy, method and technique instructional elements. The results were discussed and several suggestions were developed to be applied.
\end{abstract}

Keywords: Instruction management, higher education, instructional element, management processes 


\section{Giriş}

Yükseköğretimin temel işlevi araştırma, yetiştirme ve teknoloji üretmektir. Ortaöğretim sonrası akademik, sanat, spor ya da mesleğe yönelik alanlardaeğitim-öğretim ve yetiştirme hizmeti verilmektedir. Bu hizmetlerin sunulduğu kurumsal yapıların başında üniversiteler gelmektedir. "Bilimsel özgürlüğe sahip tüzel bir kişiliğe sahip olan üniversite, fakülteler, yüksekokullar, enstitüler ve bölümlerle eğitim-öğretim, bilimsel araştırma, yayın ve danışma hizmetlerini gerçekleştirir" (Drew ve Klopper, 2014; Eurydice, 2016; Kerr, 2001).

Araştırma ile bilgi üretimi; teknolojiyle bilginin günlük yaşama dönüştürülmesi ve yetiştirmeyle gençleri eğitmek ve gerçek hayata ve geleceğe hazırlamak amaçlanır. Yetiştirme hizmetinin yerine getirilmesinde öğretimin etkili, verimli ve kaliteli biçimde gerçekleştirilmesi kilit öneme sahiptir. Öğretim, öğrencilerin bilgi ve becerileri edinmesini sağlayan bir süreçtir (Dumont, Istance, Benavides, 2010; Fidan, 2012; Senemoğlu, 2009). Bu süreci gerçekleştirebilmek için öğretim üyelerinin, uzmanlık alanlarına ilişkin bilgi ve becerilerinin yanı sıra öğretimi yönetme becerilerine de sahip olması gerekir.Alan bilgi ve becerisi çok iyi olmasına rağmen iyi yönetilemeyen öğretim sebebiyle öğrencilerin öğrenmesi ve yetişmesi oldukça sınırlanabilir (Akpınar-Wilsing ve Paykoç, 2004; OECD, 2017; UNESCO, 2014).

Yükseköğretimde öğretimin etkili, verimli, kaliteli şekilde gerçekleştirilebilmesi öğretim görevlilerinin bu alanda uzmanlaşmasıyla mümkün olabilir. Öğretimin yönetilmesi öğretim görevlilerinin yeterlik alanlarından biri olarak görülmelidir (Akpınar-Wilsing ve Paykoç, 2004; Brown ve Atkins, 1988; Kürüm, 2007). "Öğretimin yönetilmesi, yönetim kavram, ilke, kuram ve süreçlerinin öğretim faaliyetlerine uygulanmasıdır." (Yıldırım ve Aslan, 2019).Öğretim faaliyetlerinin temel unsurları felsefe, amaçhedef, öğrenci özellikleri, fiziki çevre-araç-teknoloji, öğretim modelyöntem-teknikleri ile zaman-süredir (Berner, 2013; Fidan, 2012; Hirsch, 2003; Schunk, 2011; Senemoğlu, 2009). Yönetim süreçleri (YS) planlama, organize etme, örgütleme, yöneltme (harekete geçirme), koordine etme, kontrol, değerlendirme ve raporlama işlemlerini içine almaktadır (Hoy ve Miskel, 2012; Lunenburg ve Ornstein, 2012; Stringer, Christensen ve Baldwin, 2010). 
Planlama, geleceğin tasarlanmasıdır. Öğretimin niçin, ne zaman, ne kadar sürede, kimle, neyle ve nasıl gerçekleştirileceğine ilişkin bir tasarlamadır. Bu tasarıda öğretimin maliyeti de dikkate alınmalıdır. Organizasyon, öğretim esnasında kimin ne yapacağını ortaya koymaktır. Örgütleme, öğretim uygulamasının gerçekleştirilmesinde aktörlere görevlerinin bildirilmesi ve bu görevleri yerine getirebilmeleri için onlara ihtiyaç duydukları bilgi, beceri ve tutumunun kazandırılmasıdır. Yöneltme ya da uygulamaya geçme (başlatma ve sürdürme), çok çeşitli iletişim yollarıyla öğretim uygulamasının başlaması için gerekli harekete geçirme uyarıcılarının verilmesidir. Yöneltme hem iletişim hem de motivasyon konularını barındırmaktadır. Öğretim sırasında aynı anda birden fazla işin birbiriyle uyumlu şekilde gerçekleştirilmesini sağlamaktır. Yapılan bir faaliyet, diğer faaliyeti engellememeli ya da onu zayıflatmamalıdır. Raporlama, ölçme ve değerlendirme uygulamalarının formlara dökülmüş halidir. Öğretimin ne kadar etkili, verimli ve kaliteli olduğuna ilişkin tutulan kayıtlardır. Bu kayıtlar, öğretimin geliştirilmesi açısından kilit rol oynamaktadır (Cangelosi, 2014; Fisher, 2007; Taylor ve MacKenney, 2008; Vieluf, Kaplan, Klieme ve Bayer, 2012; Wiseman ve Hunt, 2014).

Yükseköğretimde öğretimin başlıca paydaşları öğretim görevlileri, öğrenciler ve destek personeli ile yöneticilerdir. Yükseköğretimde Öğretimin Yönetimi (YÖY) paydaşların ortak katkısıyla gerçekleştirilmekle birlikte en büyük sorumluluk öğretim görevlisinindir. Yükseköğretimin dinamik ve rekabete açık yapısı gereği öğretim görevlilerinin ihtiyaca cevap verebilecek bir öğretimi nasıl gerçekleştirebilecekleri problemli bir alandır (Doğanay ve Yeşilpınar-Uyar, 2019; Kürüm, 2007). Örneğin farklı özelliklere sahip öğrencilerle, sürekli yenilikler sunan teknolojiyle, artma eğilimindeki çok kültürlü sınıflarla öğretim,oldukça zorlayıcı bir meseledir (OECD, 2016). Bu zorluğun bir parçasını ise hızla dijitalleşen hizmet, ürün ve ilişkilerin gerçek yaşamda dayattığ1 değişimler oluşturmaktadır. Yükseköğretimde yetiştirme hizmetinin sunumu da dijitalleşmenin dayattığı değişimden bağımsız değildir. Öte yandan yükseköğretimde "kalite yönetim süreçleri"ni uygulama ve "eğiticilerin eğitimi" kapsamında öğretim elemanlarının pedagojik ilkeleri derslerinde uygulamaları, geliştirilmeye çalışılmakta ve bu durum "Yükseköğretim Yeterlikler Çerçevesi"nin odak konularından birini oluşturmaktadır (YÖK, 2019). 
Bir yanda kaliteli öğretim baskısı diğer yanda dijital çağın gereklerine uyabilme isteği yükseköğretim düzeyinde keskinleşme eğilimi olan bir probleme dönüşmüştür. Bu problemin çözümüne yönelik arayışlar söz konusudur. Literatürde yükseköğretimde eğitim-öğretim kalitesi sorunları iletilmektedir (Çetinsaya, 2014; Doğanay ve Yeşilpınar-Uyar, 2019; Houstan, Meyer and Paewai, 2006; Kavak, 2011; Kürüm, 2007; Leibowitz, Bozalek, SchalkwykandWinberg, 2015; Mårtensson, K., Roxå, T. \& Olsson, 2011; OECD, 2009; OECD, 2008). Örneğin Doğanay ve YeşilpınarUyar (2019) tarafından gerçekleştirilen çalışmada araştırma görevlilerine yönelik bir ders amaç, içerik, öğretim-öğrenme ve değerlendirme boyutları açısından incelenmiş ve öğretimin ihtiyaç ve beklentileri karşılamadığı saptanmıştır. Bu tür sorunların çözümüne yönelik yükseköğretimde öğretimi daha kaliteli hale getirme çabaları bildirilmektedir (Fisher, 2007; Rogers, 2003; Schleicher, 2016; Taylor ve MacKenney, 2008; Vieluf et al., 2012; Wiseman ve Hunt, 2014). Çabaların özellikle "öğrenen odaklı öğretimi gerçekleştirme" ve "öğretim görevlilerinin öğretim becerilerinin geliştirilmesine" odaklandığı bildirilmektedir (Doğanay ve YeşilpınarUyar, 2019). Özellikle Bologna süreci kapsaminda öğretim-öğrenme süreçlerinin etkili, verimli ve kaliteli hale getirilmesi vurgulanmaktadır (YÖK, 2019). Bu çabaların sistemli ve bütüncül şekilde öğretim görevlilerinin faydalanmasına sunulma ihtiyacı saptanmaktadır (Ünver, 2013). Bu çerçevede, Türkiye'de yükseköğretim düzeyinde öğretim konulu çalışmaların oldukça sınırlı olduğu söylenebilir. Araştırma boşluğunun yanı sıra yönetim süreçlerinin öğretime uygulanmasıyla pedagojik ilkelerin pratik şekilde uygulamaya nasıl aktarılabileceği aşamalı şekilde görülebilir. Öğretim görevlileri, öğretimin farklı boyutlarını görerek gerçekleştirme fırsatı elde edebilirler. Kilit önemde noktalar saptanarak öğretimi daha etkili hale getirebilmeleri sağlanabilir. Yükseköğretim düzeyinde öğretimi daha etkili hale getirebilecek ipuçlarının elde edilebilmesi yönünde alanyazın taranarak veriler toplanabilir. Alanyazın hem iyi uygulama örneklerini hem yaşanan sorunları ve bu sorunların çözümü için geliştirilen önerileri barındırabilir. Bu nedenle alanyazın taraması yoluyla yükseköğretimde öğretimin daha etkili gerçekleştirilmesine hizmet edebilecek bulgular elde edilebilir.

$\mathrm{Bu}$ çalışmada literatür incelemesine dayalı olarak öğretimsel ögelere ilişkin iyi örnekler, sorunlar ve çözüm önerilerinin saptanması amaç- 
lanmaktadır. Bu amacı gerçekleştirebilmek için daha sistematik bir yaklaşımla yönetim süreçleri açısından öğretimsel ögelerin aşamalandırılarak incelenmesine, sınıflandırılmasına ve pratik uygulamaya hizmet edecek biçimde sunulmasına çalışılmaktadır. Bu çalışmada gözetilen bir başka boyut ise dijitalleşmenin sağladığı fırsatların öğretimi daha etkili kılmada nasıl kullanılabileceğini ortaya koyabilmektir. Böylelikle, öğretimi etkili ve kaliteli şekilde gerçekleştirebilmeye hizmet edebilecek bir uygulama önerisi geliştirilebilir.

\section{Yöntem}

Bu çalışmada, dijital dönemin fırsat ve tehditleri altında yönetim süreçlerinin yükseköğretim düzeyinde öğretime nasıl uygulanabileceğinison beş yılda yapılmış yayınlar üzerinden incelenmesi amaçlandığındannitel araştırma desenlerinden içerik analizi ilkeleri izlenmiştir.İçerik analizinde temel veriler kitaplar, tezler, gazeteler, romanlar, dergiler gibi dokümanlardan elde edilmektedir (Fraenkel, Wallen and Hyun, 2012). İlgili dokümanların belirlenmesi ve incelenmesinde üç aşamalı bir elek kullanılmıştır. Öncelikle ilgili dokümanlara erişebilmek için bir şablon geliştirilmiştir. Elde edilen dokümanlar sınıflandırılmış ve kasıtlı örneklemeyle incelenecek olanlar seçilmiştir. İçerik analizinin nasıl yapılacağı belirlenerek dokümanların analizi gerçekleştirilmiştir.

\section{Veri toplama ve inceleme}

Doküman evrenine ulaşabilmek için kullanılan elek aşamalı şekilde zaman, doküman türü ve içerik gözeneklerini içermekteydi. Buna göre dokümanların son beş yıl içinde tam metin basımı ya da yayımı yapılmış olmasına dikkat edilmiştir. Ardından doktora tezleri (T), makaleler (M) ve kitaplar (K) seçilmiştir. Bunlar arasındanyönetim süreçleri(YS), öğretim (Ö) dijital dönemin özellikleri (D) içeriğine odaklı olan dokümanlar tespit edilerek sinıflanmıştır. Dokümanlara ulaşmada Thomson-Reuters Web of Science, Academic Search Complete, ProQuest, OECD iLibrary, Ebook Central ve Ulakbim Sosyal Bilimler Veri Tabanı gibi bilindik arama motorlarına "yönetim süreçleri-management 
process", "öğretim /yetiştirme-instuction/teaching" ve "dijital-digital" anahtar kelimeleri girilmiştir. Aramalar 02 Ocak - 14 Ocak 2019 tarihleri arasında gerçekleştirilmiştir.Doküman arama süreci sonunda tespit edilen toplam 195 doküman araştırmanın evrenini oluşturmuştur. Amaçlı ve tabakalı tesadüfi örnekleme ile örneklem alınmıştır (Fraenkel, Wallen ve Hyun, 2012). Bu süreçte dokümanlar yer aldıkları tabakaya göre kodlanmıştır. Kodlamada YS, Ö ve D türleri ( $\mathrm{YS}_{1}, \mathrm{YS}_{2}, \mathrm{YS}_{3}, \ldots \ddot{O}_{1}, \ddot{\mathrm{O}}_{2}$, $\ddot{\mathrm{O}}_{3} . . \mathrm{D}_{1}, \mathrm{D}_{2}, \mathrm{D}_{3} \ldots$ ), birer tabaka olarak tanımlanmıştır. Her bir tabakanın $\%$ 25'i tesadüfi alınarak örneklem seçilmiştir. Bu seçilenlere ek olarak her bir tabakadan farklı içerikleri temsilen üçer doküman, araştırmanın amacı doğrultusunda, kasitlı şekilde belirlenmiştir. Tablo 1, örneklemdeki dokümanların içerik ve türe göre dağılımını göstermektedir. Tabloya göre 15 doküman yönetim süreçleriyle; 24 doküman öğretimle ve 10 doküman da dijital özelliklerle ilgilidir.

Tablo 1. Dokümanlarn türü ve içeriğine göre örnekleme girenler

\begin{tabular}{lllll}
\hline Doküman türü & YS & Ö & D & Toplam \\
\hline $\mathrm{T}$ & 2 & 9 & 2 & 13 \\
$\mathrm{M}$ & 2 & 5 & 1 & 8 \\
$\mathrm{~K}$ & 8 & 7 & 4 & 19 \\
Amaçlı seçilen & 3 & 3 & 3 & 9 \\
\hline Toplam & 15 & 24 & 10 & 49 \\
\hline
\end{tabular}

Sistematik bir yoldan dokümanların içeriklerini incelemek ve bulguları raporlayabilmek için bir matris üretilmiştir. Matrisin sütunlarında altı boyuttan oluşan öğretimsel ögeler ve satırlarında ise dört boyuttan oluşan yönetim süreçleri yer almıştır.

Yönetim süreçlerinde planlama; hedef ve amaçları belirlemeyi ve bunları gerçekleştirmek için uygun yöntemi seçmeyi kapsamaktadır. Organizede ise, görevler paylaştııılır, kaynaklar tahsis edilir ve etkinliklerin koordinasyonu gerçekleştirilir. Kısaca yapı kurulur.Uygulama aşamasında eyleme geçilir, planlanmış etkinlikler gerçekleştirilir. Bu süreçte çalışanlar motive edilir, çalışanların etkinlikleri yönlendirilir, ilgili çalışanlarla iletişim kurulur ve sorunlar çözüme kavuşturulur. Son olarak, kontrol etme boyutunda çalışanların performansları gözlemlenir, söz konusu performansların amaçlara göre gerçekleştirilmesi izlenir ve sonuç olarak performans geliştirilir (Hoy 
and Miskel, 2013; Lunenburg and Ornstein, 2012; Robbins and Judge, 2013; Schermerhorn, 2012). Örnekleme alınan dokümanlar numaralandırıldı. Tek sayılı dokümanlar bir araştırmacı; çift numaralılar ise diğer araştırmacı tarafından birbirlerinden bağımsız olarak incelendi. Bulgu olarak değerlendirilebilecek temalar, matrisin ilgili hücrelerine yazıldı. Tablo 2'de matrisle ilgili kodlama ile kodlama kategorilerinin analiz edilmesi ve raporlandırılmasına ilişkin bir çerçeve sunulmaktadır (Fraenkel et al., 2012). Sonuçlar, her bir araştırmacı tarafından bağımsız olarak teyit edildi. Öğretim faktörlerinin birleştirilmesi sonucu elde eldilen temalar göz önünde bulundurularak yükseköğretimde öğretimin yönetimiyle ilgili bir model oluşturuldu.

Tablo 2. Dokümanları incelemede kullanılan matris

\begin{tabular}{lcccc}
\hline $\begin{array}{l}\text { Öğretim ve yönetim süreçlerinin } \\
\text { teorik boyutları }\end{array}$ & Planlama Organizasyon & $\begin{array}{c}\text { Uygulama } \\
\text { (Başlatma ve } \\
\text { Sürdürme) }\end{array}$ & $\begin{array}{c}\text { Denetim (Ölçme } \\
\text { ve } \\
\text { değerlendirme) }\end{array}$ \\
\hline Felsefe, amaç ve hedefler & $\mathrm{F}_{\mathrm{p}}$ & $\mathrm{F}_{\mathrm{o}}$ & $\mathrm{F}_{\mathrm{y}}$ & $\mathrm{F}_{\mathrm{k}}$ \\
Model, metot ve teknikler & $\mathrm{M}_{\mathrm{p}}$ & $\mathrm{M}_{\mathrm{o}}$ & $\mathrm{M}_{\mathrm{y}}$ & $\mathrm{M}_{\mathrm{k}}$ \\
Çocukların özellikleri & $\mathrm{Çp}_{\mathrm{p}}$ & $C_{\mathrm{o}}$ & $C_{\mathrm{y}}$ & $C_{\mathrm{k}}$ \\
Ortam, materyal ve ekipman & $C_{\mathrm{e}}$ & $C_{\mathrm{e}}$ & $C_{\mathrm{e}}$ & $C_{\mathrm{y}}$ \\
Teknoloji & $\mathrm{T}_{\mathrm{p}}$ & $\mathrm{T}_{\mathrm{o}}$ & $\mathrm{T}_{\mathrm{y}}$ & $\mathrm{T}_{\mathrm{k}}$ \\
Zaman ve süre & $\mathrm{Z}_{\mathrm{p}}$ & $\mathrm{Z}_{\mathrm{o}}$ & $\mathrm{Z}_{\mathrm{y}}$ & $\mathrm{Z}_{\mathrm{k}}$ \\
\hline
\end{tabular}

\section{Geçerlik ve Güvenirlik}

Araştırmanın amacı belirtilerek bu amaca yönelik bulgular sunulmuş ve alanyazın ile karşılaştırılmıştır. Bununla birlikte araştırmanın anahtar kelimeleri olan yönetim süreçleri, yükseköğretim, öğretim ve öğretimin ögeleri ile dijital dönemin özelliklerine ilişkin kavramsal açıklamalar verilmiştir. Ayrıca bu çalışmada incelenen dokümanların künyeleri kaynakçada belirtilmiştir. Verilerin nasıl toplanıp incelendiği detaylı ve açık bir şekilde sunulmuştur. Verilerin analizi sırasında araştırmacılar test yarılama yöntemiyle aynı tür ve aynı içerikteki dokümanları ikiye ayırarak bağımsız şekilde incelemişlerdir. Araştırmacılar, bulgularını Tablo 2'de gösterilen ortak bir forma işlemişlerdir. Daha sonra bulgular karşılaştırılarak ortak formlar üretilmiştir. Bu araştırmada elde edilen sonuçlar önceki araştırma sonuçlarıyla ve modellerle karşılaştırılmıştır. Örneğin Hattie (2012) ve Marzano (2007) çalışmalarıla yapılan 
karşılaştırma ölçüt geçerliğini desteklemektedir. Bununla birlikte araştırmada elde edilen sonuçlar halen yükseköğretim düzeyinde öğretim yapan üç öğretim elemanının görüşüne sunulmuştur. Böylece yordama geçerliği sağlanmaya çalışılmıştır. Öğretim elemanları, öğretim etkinliklerine ilişkin açıklamaların yetersiz olduğunu belirtmekle birlikte ortaya konulan aşamalı uygulama önerisinin uygulanabileceğini vurgulamışlardır. Bağımsız uzman görüşleri doküman analizine dayalı elde edilen bulgulara yönelik olduğundan literatürde "yükseköğretimde öğretim etkinlikleri" konusunda bir çalışma boşluğuna işaret etmektedir.

\section{Bulgular}

Bu çalışmada doküman incelemesinden elde edilen bulgular, araştırmanın alt amaçlarına göre Tablo 2'deki matris doğrultusunda sunulmuştur.

\section{Öğretimi Planlamaya İlişkin Bulgular}

Öğretimin planlaması, öğretimin bütün ögelerini kapsayacak şekilde incelenmiş ve elde edilen bulgular felsefe $(\mathrm{F})$, yöntem $(\mathrm{Y})$, öğrencilerin özellikleri (Ö), ortam $(\mathrm{O})$, teknoloji (Te) ve zaman $(\mathrm{Z})$ ögeleri bakımından ayrı ayrı sunulmuştur. Planlama sürecinde toplam 142bilgi parçası saptanmıştır. Ortak yönleri dikkate alınarak bu ögeler temalandırılmıştır. Tablo 3, öğretimin planlamasına ilişkin elde edilen bulguları içermektedir.

Planlamanın ilk adımında felsefe, amaç ve hedefler dikkate alınarak dokümanlarda yer alan bilgi parçalarıbelirtilmiştir. Toplam 63 adet bilgi parçası saptanarak bunlar altı tema altında özetlenmiştir. Bu temalar öğrencinin öğrenmesi, gelecekteki beceriler, gelişim ve ürün, bağlam, müfredat ve öğretenin öğrenmesi şeklinde adlandırılmıştır. Model-Strateji-Yaklaşım alt başlığ altında ise toplam 31 öğretimsel öge saptanmış ve dört tema altında özetlenmiştir. Öğrenci özellikleri başlı̆̆ı altında toplam 14 ögeye yer verilmiş olup bunlar üç tema altında özetlenmiştir. Ortam (öğrenme ortamı, materyal, ekipman) iki tema altında toplam 14 ögeyi içermiştir. Teknolojiöğretimsel ögesinde üç tema altında toplam 17 bilgi parçası bulunmuşt ur. Son öge zaman ögesidir. Bu ögenin planlanmasına ilişkin üç bilgi parçası belirlenmiş olup, bireysel farklılıkların dikkate alınarak sürenin ve zamanın planlanmasını açıklamaktadır. 
Tablo 3. Öğretimi planlama sürecine ilişkin bulgular

\begin{tabular}{|c|c|c|c|}
\hline Öge & Tema & Bilgi Parçaları & $f$ \\
\hline \multirow{6}{*}{ 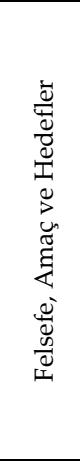 } & $\begin{array}{l}\text { Öğrencinin } \\
\text { öğrenmesi }\end{array}$ & $\begin{array}{l}\text { Öğretim sürecini iyileştirme, anlam oluşturma, deneyimleri } \\
\text { kullanma }\end{array}$ & 7 \\
\hline & $\begin{array}{l}\text { Gelecekteki } \\
\text { beceriler }\end{array}$ & $\begin{array}{l}\text { Çoklu okuryazarlık, yaratıcılık, girişimcilik, işbirliği, iletişim, } \\
\text { eleştirel düşünme, problem çözme, karar verme, programlama, } \\
\text { algoritma yazma }\end{array}$ & 21 \\
\hline & Gelişim ve ürün & $\begin{array}{l}\text { Öğrenci katılımı, öğrenme çıktılarını sunma sosyal-duygusal alanı } \\
\text { sürece katmak }\end{array}$ & 13 \\
\hline & Bağlam & $\begin{array}{l}\text { Pedagojik uygunluk, öğretimin bağlamla birleştirilmesi, duvarların } \\
\text { dışına çıkmak }\end{array}$ & 7 \\
\hline & Müfredat & $\begin{array}{l}\text { Açık, net hedefler, mevcut müfredatın ötesine geçmek, umut ve } \\
\text { beklentiler oluşturma }\end{array}$ & 11 \\
\hline & $\begin{array}{l}\text { Öğretenin } \\
\text { öğrenmesi }\end{array}$ & Öğrenme ortamına girme, paylaşma, deneme & 4 \\
\hline \multirow{4}{*}{ 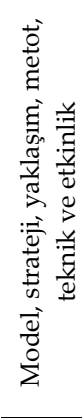 } & $\begin{array}{l}\text { Pedagojik } \\
\text { Kuramlar }\end{array}$ & $\begin{array}{l}\text { Temel pedagojik kuram bilgisi (Örn. Dewey, Bandura, Vygotsky, } \\
\text { Froebel...), kuramlarla uygulama bağı kurma, kuramlar arasında } \\
\text { sentezleme, dijital döneme uyumlu kendi pedagojik portföyünüzü } \\
\text { oluşturma }\end{array}$ & 13 \\
\hline & $\begin{array}{l}\text { Farkli } \\
\text { pedagojik } \\
\text { yaklaşımlar }\end{array}$ & $\begin{array}{l}\text { Bütüncül eğitim, yenilikçi yaklaşımlar, gözlenemeyen bilişsel } \\
\text { unsurları keşfetme, beden-zihin-duygu ve sosyal yönden zengin } \\
\text { pedagoji }\end{array}$ & 9 \\
\hline & $\begin{array}{l}\text { Pedagojik } \\
\text { Repertuar }\end{array}$ & $\begin{array}{l}\text { Zengin pedagojik karışım, işlem ve dönüştürme, proje temelli, } \\
\text { araştırma temelli, problem temelli öğretim }\end{array}$ & 5 \\
\hline & $\begin{array}{l}\text { Pedagojik } \\
\text { Uygulamalar }\end{array}$ & $\begin{array}{l}\text { İşbirlikli liderlik, eğlenme, sınıf tartışmaları, oyunlaştırma, gerçek } \\
\text { hayattan ve sosyal problemlerin çalışılması }\end{array}$ & 4 \\
\hline \multirow{3}{*}{ 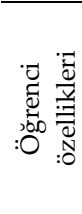 } & $\begin{array}{l}\text { Öğrencileri } \\
\text { tanımak }\end{array}$ & $\begin{array}{l}\text { Bireysel farklılıklar, öğrencileri tanıma, saygı, lojistik öğrenme, } \\
\text { öğrenmeyi kolaylaştırıcı ortamı düzenleme }\end{array}$ & 6 \\
\hline & Öğrenci ve çevre & $\begin{array}{l}\text { Çevreyle etkileşim, birlikte çalışma, sosyal ve kültürel yön, } \\
\text { etkileşim ve öğrenme }\end{array}$ & 5 \\
\hline & $\begin{array}{l}\text { Öğrenciye } \\
\text { göre pedagoji }\end{array}$ & Öğrenciye göre pedagojik uygunluk, öğrencileri destekleme, ilgi & 3 \\
\hline \multirow[b]{2}{*}{ E్త్ర } & Öğrenme ortamı & $\begin{array}{l}\text { Yapı-tarz, teknoloji ve ortam uyumu, öğrenme deneyimleri } \\
\text { teknoloji destekli esnek öğrenme ortamı, öğrenci ihtiyacı }\end{array}$ & 4 \\
\hline & Materyal & $\begin{array}{l}\text { Özelleşmiş materyaller, materyal bilgisi, materyal motive edici ve } \\
\text { eleştirel düşünmeyi tetikleyici olmalı, materyal kullanımını } \\
\text { planlama, güncelleme, maliyet-fayda }\end{array}$ & 10 \\
\hline \multirow[b]{2}{*}{ 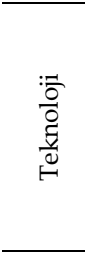 } & $\begin{array}{l}\text { Teknoloji } \\
\text { dostu gençler }\end{array}$ & Teknolojiyle içiçe, dijital okur-yazarlık, yaratıcı, fırsat vermek & 4 \\
\hline & $\begin{array}{l}\text { Teknoloji } \\
\text { destekli öğretim } \\
\text { Teknoloji } \\
\text { entegrasyonu } \\
\text { uyarılar }\end{array}$ & $\begin{array}{l}\text { Teknolojiyle planlama, programcılık, yapılandırmacılık, bireysel } \\
\text { ihtiyaçlara duyarlık, anında dönüt, kişisel bilgi oluşturulması } \\
\text { Öğrenmeye katkısı, teknoloji ve geleneksel öğretim, teknolojik } \\
\text { vefırsatlara duyarsızlık ve bilgisizlik, tekno-pedagojik bilgi ve beceri, } \\
\text { teknoloji bağımlılığı, sosyal-duygusal etkiler }\end{array}$ & 6 \\
\hline 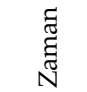 & $\begin{array}{l}\text { Zamanlama } \\
\text { süre }\end{array}$ & $\begin{array}{l}\text { veÖğretim zamanı, bireysel farklılıklar ve öğretim süresi, öğretim } \\
\text { kalitesini artırarak öğretim süresini kısaltma }\end{array}$ & 3 \\
\hline
\end{tabular}


Öğretimin planlamasında "Öğrencilerin neyi bilmesini, hangi becerilere ve tutumlara sahip olmasın bekliyoruz?" sorusu ön plana çıkmaktadır. Öğrencilerin bu bilgi, beceri ve tutumlarını kazanmalarını sağlamak için öğretim görevlilerinin hangi becerilere sahip olması sorusu anlam kazanmaktadır. Öğretim görevlileri, bir öğretimin planlanmasında hangi modelleri, stratejileri, metotları ve ilkeleri göz önünde bulundurmalıdırlar? Bu sorular, öğretimin uygulanmasının nasıl planlanabileceği üzerinde çok önemli rol oynamaktadır. Öğretimi planlamada özellikle duvarların dışına çıkmayı, gerçek hayat içinde öğrenmenin gerçekleştirilmesi vurgulanmaktadır. İzlenebilecek model, strateji ve yöntemler arasında bütüncül yaklaşım sıklıkla belirtilmekte ve proje temelli araştırma ve bilimsel süreçleri içeren öğretim yaklaşımları öne çıkmaktadır. Öğrenciyi tanıma ve bireysel farklılıkları dikkate alan öğretim uygulamaları sıklıkla vurgulanmaktadır. Teknolojinin sunduğu fırsatların kullanılabilmesi için farkındalık ve uygulama bilgisinin önemli bir engel olarak belirdiği gözlemlenmektedir. Teknolojik fırsatlar açısından bir başka boyut insan unsurunun öğretim açısından şu anda ikame edilemeyeceğidir. Teknoloji, öğretimi daha etkili kılmada destekleyici bir öge olarak vurgulanmaktadır.

\section{Öğretimi Organize Etmeye İlişkin Bulgular}

Bu bölüm, kısaca kimin neyi yapacağını belirlemeye odaklanmaktadır. Yönetim süreçleri açısından yapıyı kurma karşılığı olarak görülebilir. Öğretimi organize etmenin bulguları Tablo 4'te gösterilmektedir. 15 tema altında toplam 116bilgi parçası bulunmuştur. Öğretimi organize etme sürecinin öğretimsel ögelere göre tema ve bilgi parçalarının vurgulanma sıklığı dikkate alındığında Felsefe, amaç ve hedef ögesi iki tema altında toplam 25 bilgi parçasını içerdiği fark edilmektedir. Model, yaklaşım ve yöntem öğretimsel ögesinde ise beş tema altında 37 bilgi parçası saptanmıştır. Öğrenci özellikleri iki tema altında toplam 10 adet bilgi parçasını içermiştir. Ortam, materyal, ekipman öğretim ögesi ise iki tema altında toplam 20 bilgi parçasını içermektedir. Teknoloji ögesi üç temayla temsil edilmiş ve toplam 21 bilgi parçasını içermiştir. Son öge olan zaman ögesi ise üç bilgi parçasını içermektedir. 
Tablo 4. Öğretimi organize etme sürecine ilişkin bulgular

\begin{tabular}{|c|c|c|c|}
\hline Öge & Tema & Bilgi Parçaları & $f$ \\
\hline \multirow{2}{*}{ 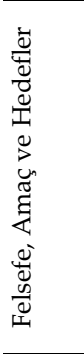 } & $\begin{array}{l}\text { İşbirliği ve } \\
\text { sorumluluk }\end{array}$ & $\begin{array}{l}\text { Sürekli öğrenme, sorumlulukların paylaşımı, öğrencilere yardım ve } \\
\text { yönlendirme, öğrencilerin görüş ve fikirleri, problem çözme, daha } \\
\text { ötesine erişme (Vygotsky), net ve anlaşlır hedefler, stratejiler belirlemek, } \\
\text { işbirlikli öğrenme (Dewey), kavramlar ve kavramlar arası ilişkiler, dil- } \\
\text { süreç-araç birlikteliği, üst düzey zihinsel işlemler, yaratıcllı, düşünme- } \\
\text { eylem birlikteliği }\end{array}$ & 15 \\
\hline & Farklılaşma & $\begin{array}{l}\text { Bireysel farkllıklara cevap verme, çeşitlilik sağlama, öğrenme profilleri, } \\
\text { ihtiyaca cevap verebilecek esnekligi gerçekleştirme, merak, çoklu bakış } \\
\text { açısı, metaforik düşünme, yeni pedagojik yaklaşılar, özgünlük, } \\
\text { pragmatik yaklaşm (Dewey), bütünsel gelişim }\end{array}$ & 10 \\
\hline \multirow{5}{*}{ 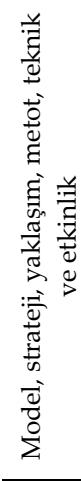 } & Modeller & Bütüncül, proje temelli, deney, harmanlanmış, kişiselleştirilmiş modeller & 5 \\
\hline & Bireysel ilerleme & $\begin{array}{l}\text { Elektronik öğrenme, öğrencilere seçenek sunma, kişisel kayıtlar ve } \\
\text { güncelleştirme, hesapverebilirlik, uygulamada unsurlar arası uyum, } \\
\text { öğrenci ilerlemesini destekleme }\end{array}$ & 8 \\
\hline & $\begin{array}{l}\text { Etkinlikleri } \\
\text { düzenleme }\end{array}$ & $\begin{array}{l}\text { Etkinlikleri aşamalandırma, sıralama, görevin karmaşıklı̆̆ı̆, farklı } \\
\text { öğretim stratejleri arasında uygulamada uyum sağlama, öğrenci ilgisi, } \\
\text { etkin katılım, araştırma, paylaşım, bireysel ve grupla öğretim, analitik- } \\
\text { sezgisel düşünmeyi gerektiren etkinlikler, tartışma, özetleme yapılması, } \\
\text { öğretim-öğrenme-değerlendirme uyumu }\end{array}$ & 13 \\
\hline & Birleştirme & $\begin{array}{l}\text { Konular, dersler ve hayatla ilişkilendirme, STEM fikrini uygulama, } \\
\text { sanatsal-sosyal-bilişsel konuları birleştirme, alet, araç, ürün üretimi }\end{array}$ & 6 \\
\hline & $\begin{array}{l}\text { Yönlendirici } \\
\text { destek }\end{array}$ & $\begin{array}{l}\text { Sosyal etkileşim, anlama ulaşma, soyut fikirler, sorumluluk üstlenme ve } \\
\text { üst düzey düşünsel etkinlikler }\end{array}$ & 5 \\
\hline \multirow{2}{*}{ 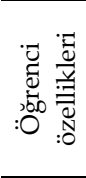 } & Bilmek & $\begin{array}{l}\text { Onların ilgilerini bilmek, öğrenciler arasındaki güç ilişkileri, öğrenci } \\
\text { bakış açısı, öğrencilerin söz sahibi olması, ögrenme yeterlikleri, } \\
\text { öğrencilerin varsayımlarına meydan okuma }\end{array}$ & 6 \\
\hline & Gerekçelendirme & $\begin{array}{l}\text { Öğrenme ihtiyaçları, gruplar oluşturma, amaç belirleme, öğrenme } \\
\text { etkinliklerine katılım }\end{array}$ & 4 \\
\hline \multirow[t]{2}{*}{ Е్ } & $\begin{array}{l}\text { Ortamı } \\
\text { değiştirme }\end{array}$ & $\begin{array}{l}\text { Ortamı dönüştürmek, dijital platformların kullanılması, ders } \\
\text { mekanizmasında esneklikler, ögretim sürecinde teknolojiden } \\
\text { faydalanma, rollerde değişim, dijital ortamı bilişsel ve sosyal } \\
\text { becerilerin ediniminde kullanma, dijital teknoloji bilgisi, vidyo } \\
\text { kullanımı, elektronik portfolyo, bireyselleşmeyi dikkate almak }\end{array}$ & 14 \\
\hline & Materyal & $\begin{array}{l}\text { Materyaller ve öğretim etkililiği, eserler, kültürel unsurlar, dinamik } \\
\text { ağ oluşturma, çoklu duyuyu uyarabilme }\end{array}$ & 6 \\
\hline \multirow{3}{*}{$\begin{array}{l}: \frac{1}{0} \\
\frac{0}{0} \\
\frac{\overrightarrow{0}}{0}\end{array}$} & $\begin{array}{l}\text { Gelenekle } \\
\text { teknoloji birleşimi }\end{array}$ & $\begin{array}{l}\text { Geleneksel öğretim uygulamalarının teknolojiyle desteklenmesi, } \\
\text { bireysel öğrenmeyi destekleme, teknolojnin grupla öğretimde } \\
\text { kullanılması, Internet, kamera, dokunmatik ekranlar, vb. kullanımı, } \\
\text { diijital öğrenme uygulamaları, }\end{array}$ & 13 \\
\hline & $\begin{array}{l}\text { Gelecek } \\
\text { vaadeden teknoloji }\end{array}$ & $\begin{array}{l}\text { Bulut teknolojisi, kaynaklara erişim, veri analizi, bilgi işleme, } \\
\text { harmanlanmış uygulamalar, }\end{array}$ & 4 \\
\hline & $\begin{array}{l}\text { Makro ile } \\
\text { entegre mikro }\end{array}$ & $\begin{array}{l}\text { Dijital ortam aracillğıyla katılım, veri işleme sistemleri, bireysel } \\
\text { verilerden toplu verilere erişim, blockchain teknolojisi }\end{array}$ & 4 \\
\hline $\begin{array}{c}\text { శ్ } \\
\text { స్ } \\
\text { N }\end{array}$ & $\begin{array}{l}\text { Zamanlama } \\
\text { ve süre }\end{array}$ & $\begin{array}{l}\text { Öğretim zamanı ve süresinin öğrenmedeki etkisi, belirli bir süredeki } \\
\text { öğrenmenin verimliliği, öğretimin etkililiğ̈inde zaman ve süre }\end{array}$ & 3 \\
\hline
\end{tabular}


Farklı felsefi yaklaşımları öğretimi harmanlayarak ve düzenleyerek kullanmak mümkün müdür? Bir dizi faaliyeti aynı zamanda ve birbirlerini etkisini zayıflatmayacak şekilde düzenlemeler yapılabilir mi?. Bunun için öncelikle öğrencilerin neyi, ne zaman, nasıl ve nerede öğrenecekleri ortaya konulmalıdır. Öğretimde, öğrenenlerin tanınması ve dikkate alınması kabul edilen bir olgudur. Bu durum öğrencilerin özel bir eğitime ihtiyaç duyup duymadıkları ve öğretim diline hakim olup olmadıklarını bilmeyi gerektirir. Öğrencilerin tanınması, öğretim faaliyetlerinde hangi strateji, yöntem ve tekniklerin kullanılabileceğini belirlemeyi sağladığı gibi öğretim elemanlarının bu öğretim faaliyetlerini düzenleme şeklini de etkiler. Potansiyel teknolojiler hala öğretimde kullanılmamaktadır. Teknoloji, bireysel farklılıkları dikkate alan eğitimi de destekler. Öğretime ayrılan süre, öğretim etkili şekilde yapıldığında anlamlı hale gelir.

\section{Öğretimi Uygulamaya İlişkin Bulgular}

Tablo 5, öğretimin temel unsurları (F-felsefe, Y-yöntem, Ö-öğrenci özellikleri, O-ortam, T-teknoloji ve Z-zaman) dikkate alınarak öğretim sürecinin gerçekleştirilmesine ilişkin bulguları göstermektedir. Öğretimi gerçekleştirme motivasyonu, iletişimi ve uygulamayı içeren bir süreçtir. Bulgular, 238bilgi parçasını içermekte olup 17 tema altında toplanmıştır.

Öğretimi başlatma ve sürdürme sürecinin ilk öğretimsel ögesi 70 bilgi parçasını içeren ve dört tema altında bunları özetleyen felsefe, amaç ve hedef kısmıdır. Temalar, öğrenme hedefleri, ögretimsel yollar, ustalık ve motivasyon şeklinde adlandırılmıştır. En yoğun kısım, beş tema altında toplam 120 ögeyi içeren Model kısmıdır. Bu kısmın tema adları desenler, etkinlikler, dönüşüm ve işbirliği, oyunlaştırma ve öğretimi gözden geçirme şeklinde adlandırılmıştır. Öğrenci özellikleri ve ortam (ortam, ekipman, materyal) öğretimsel ögeleri aynı sayıda tema $(n=1)$ ve bilgi parçasını $(f=5)$ içermiştir. Teknoloji kısmı ise beş tema altında (teknolojik özellikleri yayginlaştırma, internet, dijital ortamlar, özel gereksinimli ve dezavantajl ögrenciler ile sosyalleşme) toplam 34 öğretimsel ögeyi içermiştir. Son kısım ise yalnızca dört öğretimsel ögeyi içeren zaman kısmıdır. 
Öğretimi başlatma ve sürdürme odağında öğrenci öğrenmesini en etkili şekilde sağlayabilecek öğretim faaliyetlerinin gerçekleştirilmesi yer almaktadır. Öğretimin yöneldiği temel amaçlar ise yaratıcılık, keşfetme, problem çözme, karar verme, çoklu okur-yazarlık gibi becerilerin öğrencilere kazandırılmasıdır. Öğretim yöntemlerinin öğrencinin öğrenmesini temel alacak şekilde farklılaştırılması ve duvarların dışına hatta müfredatın dışına taşabilecek şekilde çeşitlendirilmesi öne çıkmaktadır. Özellikle proje temelli öğretim yöntemleri içinde çok sayıda yöntem ve tekniği barındırdığı için sıklıkla vurgulanmaktadır. Öğrenme derinliği bir başka vurgulanan bilgi parçasıdır. Motivasyonda davranışı izleyen teşviklerin ve içsel motivasyonun vurgulandiğ 1 görülmektedir.Öğrenci öğrenmesini en etkili kılabilecek şekilde konuların küçük parçalara ayrılması, somutlaştırma, uygulama, küçük gruplar halinde çalışılması gibi teknikler dikkati çekmektedir. Öğrencilerin öğrenmesini sağlayan öğretim etkinlikleri, birbirini destekleyecek aşamalılıkta gerçekleştirilmelidir. Öğretim etkinliklerinin çok farklı yönleri geliştirici nitelikte olması, teknolojik olanakların kullanılması, gözlem ve kayıtlarla öğrenci öğrenmesinin izlenmesi ve gerekli öğretimsel uyarlamaların yapılması öne çıkmaktadır.

\section{Tablo 5. Öğretimi başlatma, sürdürme sürecine ilişkin bulgular}

\begin{tabular}{|c|c|c|}
\hline Öge & Tema & Bilgi Parçaları \\
\hline \multirow{4}{*}{ 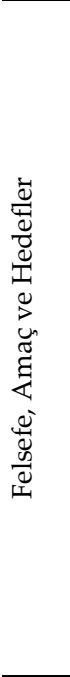 } & $\begin{array}{l}\text { Öğrenme } \\
\text { hedefleri }\end{array}$ & $\begin{array}{l}\text { 21. yüzyıl becerileri, yaratıclık, yenilik üretme, keşfetme, problem çözme, } \\
\text { karar verme, işbirliği, çok yönlü gelişim, çoklu okuryazarlık, dijital okur- } \\
\text { yazarlık, araştırma, verileri analiz etme, bulguları raporlama, bilgiyi } \\
\text { uygulama, öz-değerlendirme }\end{array}$ \\
\hline & $\begin{array}{l}\text { Öğretim } \\
\text { yolları }\end{array}$ & $\begin{array}{l}\text { Yöntem öğrenmeyi etkiler. Fırsatlar oluşturma, bütüncül yaklaşım, şimdi } \\
\text { öğrenilenin sonrakini etkilemesi, harmanlama, yaşantılara dayalı } \\
\text { öğrenme, tartışma, oyunlaştırma, zeka türü ve yöntem uyumu, hataların } \\
\text { gelişim firsatı olarak değerlendirilmesi, öz-yeterlik duygusunun gelişimi, } 25 \\
\text { başkalarını gözlemleme, çevre-kişi-davranış üçlüsü, proje bazlı öğrenme, } \\
\text { öğretmenin koçluk görevi, açılama, detaylandırma, eleştirme, } \\
\text { karşılaştırma, kavram haritaları, örnek olay, çoklu etkileşim }\end{array}$ \\
\hline & Uzmanlık & $\begin{array}{l}\text { Farklı pedagojik yaklaşımlar, farklı öğrenme tarzları, derinleşme, } \\
\text { pedagojik desenler, açı net amaçlar, katılım, anında dönüt, işbirliği, } 10 \\
\text { sorumluluk verme, olumlu öğrenme ortamı }\end{array}$ \\
\hline & Motivasyon & $\begin{array}{l}\text { Her öğrenci öğrenir, öğrenciyi nelerin motive ettiğini öğrenme, dışsal } \\
\text { ödüller (Rotter), öz-yeterlik, davranışı izleyen teşvikler, içsel motivasyon, } \\
\text { üst düzey görevlerin başarılması, içsel ödül, çaba-başarı ilişkisi, } \\
\text { öğrenilecek şeyin değeri, öğrenilecek olana ilgi, başarısızlık korkusu, }\end{array}$ \\
\hline
\end{tabular}




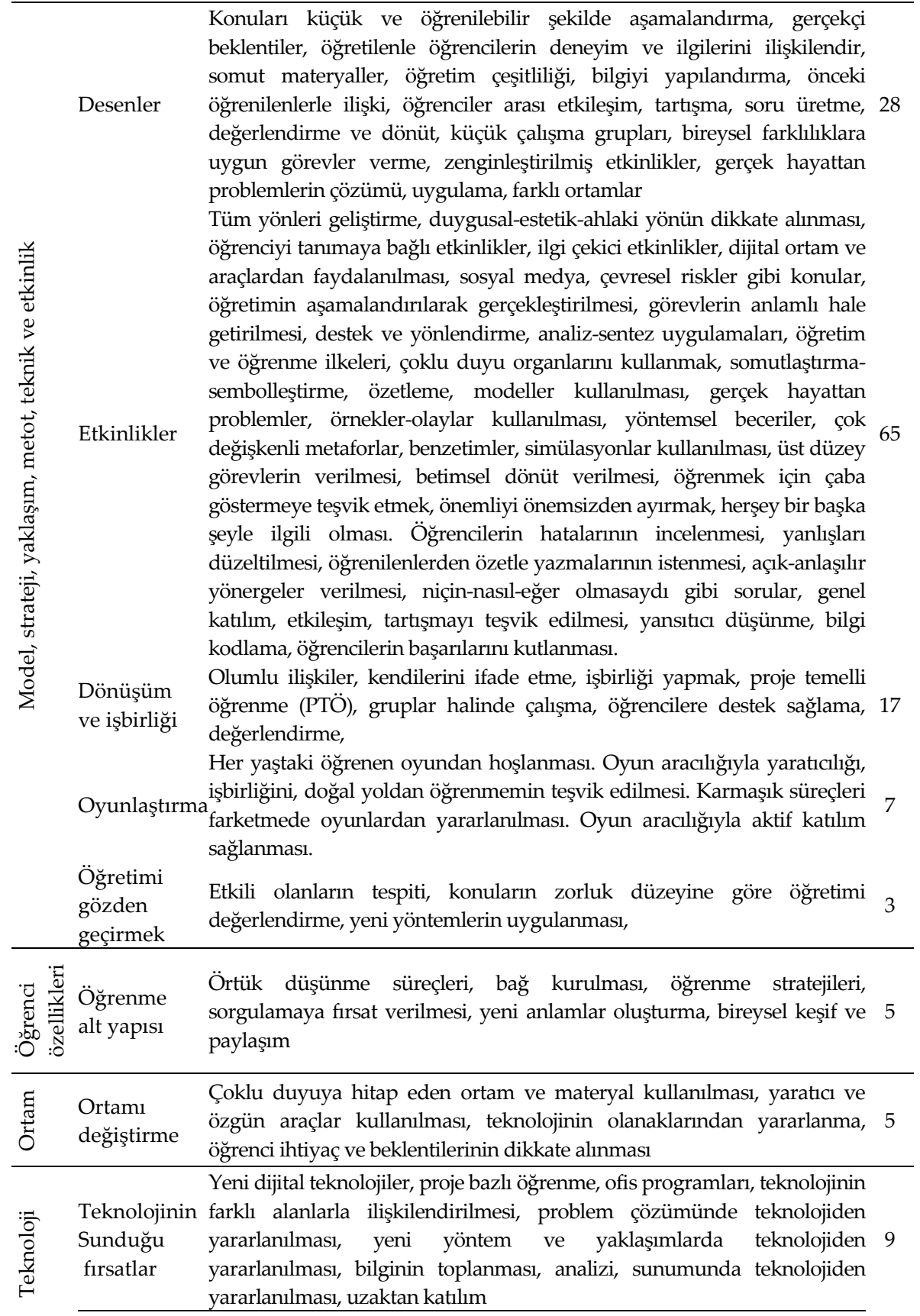




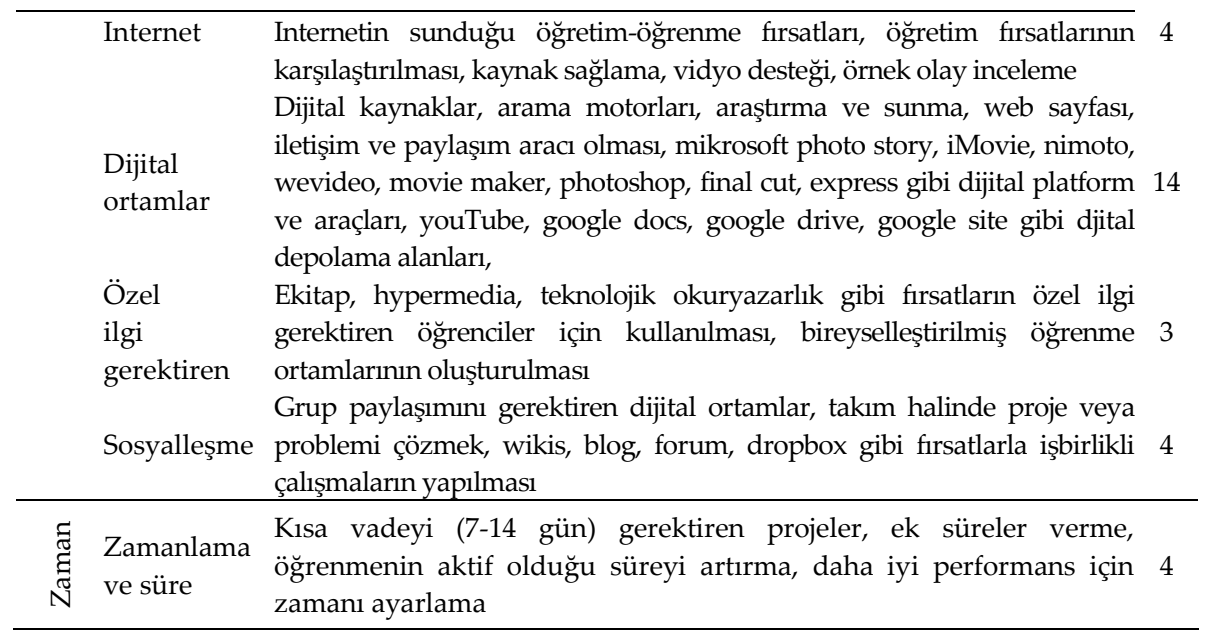

Bir başka dikkat çekici öğretimsel öge oyunlaştırmadır. Bir dersteki öğretim nasıl eğlenceli hale getirilebilir? Bir öğretimi bir oyuna ya da yarışmaya dönüştürmek mümkün müdür? Yetişkinler ve gençler de oyunlar aracılığıyla daha kolay öğrenmeler edinebilir. Oyunlar aktif katılımı ve karmaşık süreçlerin edinilmesini desteklediği için önerilmektedir. Teknolojinin olanaklarından yararlanarak çok duyuya hitap eden öğretim ortamı kurulabilir. Internet ve dijital araçların öğrenmeyi olumlu yönde destekleyici firsatlarından yararlanılabilir. Teknolojik olanaklar aynı zamanda bireysel farklılıklara duyarlı öğretimi destekleyici işlev de üstlenmektedir. Dijital ortamın sosyalleşmeyi destekleyecek şekilde takım çalışmalarına, ürün sergilemesine, değerlendirmede ekonomiklik sağladığına ilişkin bulgular yer almaktadır. Hatırlanan ya da paylaşılan bilgi okulda paydaşlarının entelektüel sermayesini biçimlendirir. Öğretim süresi ve zamanı için öğrenci öğrenmesinin temel alınması gerektiği ve öğrenmeyle sonuçlanan öğretim süresinin artırılması önerilmektedir.

\section{Öğretimin Denetlenmesine İlişkin Bulgular}

Tablo 6, öğretimin değerlendirilmesi ve geliştirilmesine odaklanan denetim süreçlerine ait bulguları göstermektedir. Bu bölümde, toplam olarak 8 tema altında 70 öğretimsel ögeye yer verilmiştir. Tabloda 
görüldüğü üzere; ilk kısım (Pc) daha iyi değerlendirme sistemleri arayışı ve etkisi yüksek sinavlar adları verilen iki tema altında toplam 26 ögretimsel ögeyi içermiştir. İkinci kısım (model, strateji...) iki tema altında 20 öğretimsel ögeyi kapsamıştır. Bu temalar nasıl değerlendiririz ve biçimlendirici değerlendirmedir. Çocukların özellikleri ve çeore, ekipman, materyal kısımlarıbirer tema içermektedir. Teknoloji kısmında ise bir tema altında toplam 13 bilgi parçası toplanmıştır. Son kısımda (Zaman ve süre) ise 4 bilgi parçasını içermektedir.

$\mathrm{Bu}$ bölümde değerlendirmenin temel işlevinin öğretimin etkililiğine ilişkin fikir edinmek olduğu vurgulanmaktadır. Öğretim ve değerlendirme, dengeli bir şekilde gerçekleştirilmelidir. Ülkede gerçekleştirilen testlerin öğretim üzerinde yıkıcı etkisi olduğu dile getirilmektedir. Özellikle biçimledirici değerlendirmelerin öğretime, öğrenmeye ve öğrenci gelişimine daha fazla katkı sunduğu ifade edilmektedir. Teknolojinin getirmiş olduğu imkanların değerlendirmede de kullanılması gerektiği anlaşılmaktadır. Bu bakımdan, teknolojinin imkanlarından oluşturulan otantik değerlendirme teknikleri sunulmaktadir.

Tablo 6. Öğretimi denetleme sürecine ilişkin bulgular

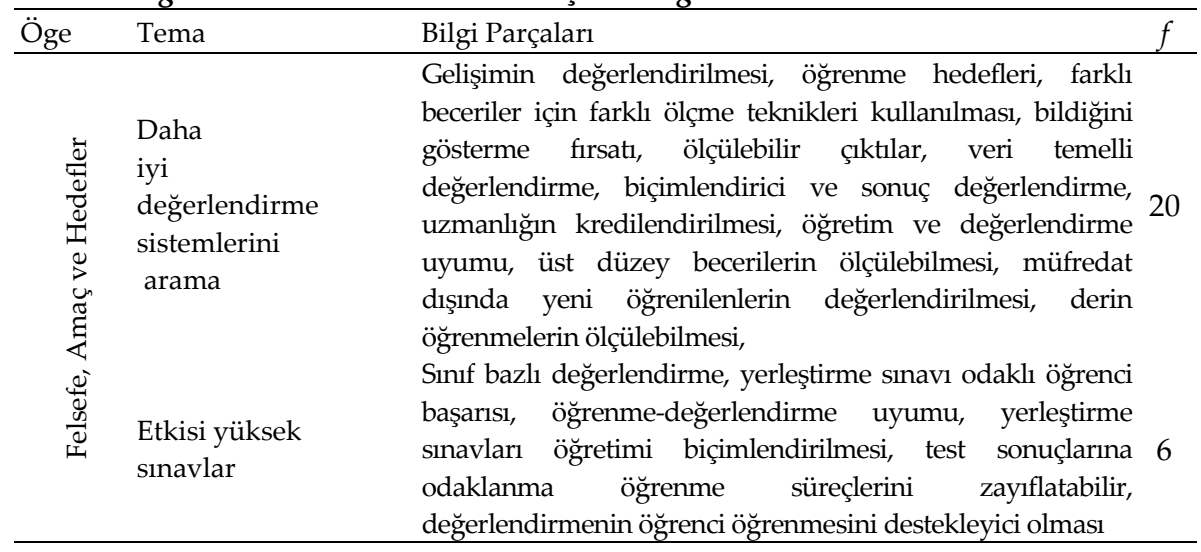




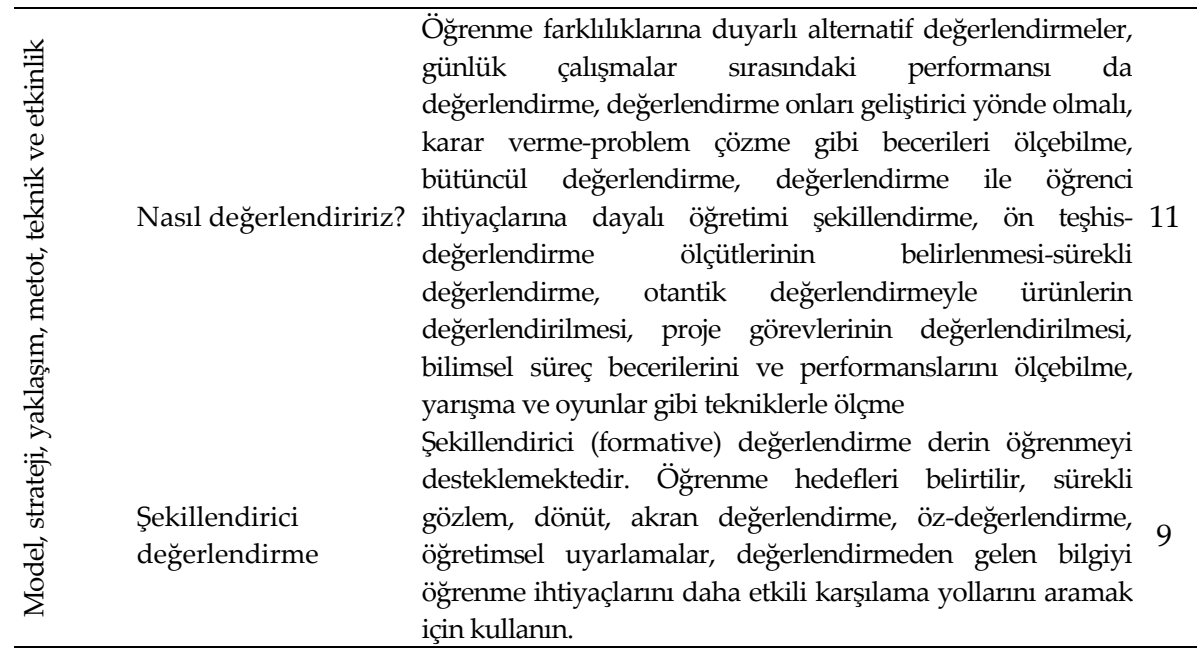

\begin{tabular}{|c|c|c|}
\hline : & Başarı duygusu & $\begin{array}{l}\text { Bireysel farklılıklar değerlendirmede dikkate alınır. Başarı } \\
\text { duygusu her öğrenciye sağlanmalıdır. Performansı } 3 \\
\text { belirleyen sayısız değişken vardır. }\end{array}$ \\
\hline 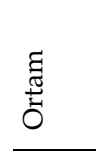 & $\begin{array}{l}\text { Gerçek } \\
\text { dünyaya } \\
\text { uygunluk }\end{array}$ & $\begin{array}{l}\text { Gerçek hayattaki problemler, özgün çözümler, kağıt- } \\
\text { kalem dışında teknoloji ve diğer araçlardan yararlanma, } \\
\text { eş zamanlı analiz, geliştirici materyallerle raporlama, } \\
\text { dijital fırsatlardan yararlanma }\end{array}$ \\
\hline $\begin{array}{l}\frac{:}{0} \\
\frac{0}{0} \\
\frac{\sqrt{0}}{\oplus}\end{array}$ & $\begin{array}{l}\text { Değerlendirme } \\
\text { aracı olarak Teknoloji }\end{array}$ & $\begin{array}{l}\text { Teknolojiyle hızlı ve etkili değerlendirme, bulut sistemleriyle } \\
\text { analiz, yapay zeka gözlem, kayıt, analiz ve öğretimi } \\
\text { uyarlamada gelecek vaadediyor. SMARTER, PARCC vb., } \\
\text { öğretimi geliştirmekte teknoloji bütüncül değerlendirme } \\
\text { firsatı sunuyor. Bilgisayar ortamında değerlendirmeler, } \\
\text { uzaktan katılımla değerlendirme, vidyo katılım, }\end{array}$ \\
\hline $\begin{array}{l}\text { శ్ } \\
\text { డ్ర్ } \\
\text { N }\end{array}$ & $\begin{array}{l}\text { Değerlendirme } \\
\text { sıklığ } 1\end{array}$ & $\begin{array}{l}\text { Ölçme ve değerlendirme süre ve sıklı̆̆ performansı etkiler, } \\
\text { teknoloji destekli uygulamalar ekonomiklik ve kolaylık } 4 \\
\text { sağlayabilir. }\end{array}$ \\
\hline
\end{tabular}

\section{Dokümanlarn İncelenmensinden Elde Edilen Nicel Sonuçlar}

$\mathrm{Bu}$ çalışmada matriks modelinden elde edilen öğretim yönetimi ve unsurlarına ilişkin nicel sonuçlar Tablo 7'de gösterilmektedir. Bu tabloda temaların ve öğretim unsurlarının nicel dağılımını görmek mümkündür. $\mathrm{Bu}$ tabloya göre öğretimin yönetiminde uygulama (başlatma ve sürdürme) (17 tema ve 238 bilgi parçası) ve planlama süreçlerinin (19 tema ve 142 
bilgi parçası) en çok vurgulanan süreçler olduğu görülmektedir. Öğretimi gerçekleştirmede planlama ve uygulamanın çoğunlukla göz önünde bulundurulduğu anlaşılmaktadır. Bu sonuçlara göre, yönetim süreçlerinin öğretime uygulamasında planlama ve uygulamanın önemli rolleri bulunmaktadır. Bilgi parçalarının yüzdelik oranları da bu durumu daha açık bir şekilde göstermektedir. Öğretimi başlatma ve sürdürmenin genel içindeki oran $\%$ 42.0; planlamanın ise \% 25.1'dir. Tablo $7^{\prime}$ de öğretimsel ögelerin nicel dağılımı incelediğinde model ve metot (Tema=16, Öğretim öğesi=219), felsefe (Tema=14, Öğretim öğesi=171) ve teknolojinin ( $\mathrm{T}=12$, Öğretim öğesi=80) en çok bahsedilen değişkenler olduğu görülmektedir. Bu ögelerin bilgi parçalarının oransal dağılımı sırasıyla \% $36.7, \% 32.5$ ve $\% \quad 15.0$ olup birlikte \% 84.2'lik bir oran oluşturmaktadırlar. Öğretimin yönetiminde en önemli unsurunplanlama ile modelin, metodun ve felsefenin uygulanması olduğu görülür. Dolayısıyla, bir öğretmenin etkili öğretim için dikkatini bu öğelere yoğunlaştırması gerektirmektedir. En az bahsedilen öğretim unsuru ise zamandir $(f=14, \% 2.5)$.

Tablo 7. Dokümanlardan elde edilen nicel sonuçlar

\begin{tabular}{|c|c|c|c|c|c|c|c|c|c|c|c|}
\hline \multirow[t]{2}{*}{ Yönetim süreçleri } & \multirow{2}{*}{\multicolumn{2}{|c|}{$\begin{array}{l}\text { Planlama } \\
\text { Tema Bilgi }\end{array}$}} & \multicolumn{4}{|c|}{ OrganizasyonUygulama } & \multicolumn{5}{|c|}{ Kontrol etme Toplam } \\
\hline & & & Tema & Bilgi & Tem & a Bilgi & Tema & Bilgi & Ten & a Bilgi & $\%$ \\
\hline Felsefe & 6 & 63 & 2 & 25 & 4 & 70 & 2 & 26 & 14 & 184 & 32.5 \\
\hline Model, metot & 4 & 31 & 5 & 37 & 5 & 120 & 2 & 20 & 16 & 208 & 36.7 \\
\hline Öğrenci özellikleri & 3 & 14 & 2 & 10 & 1 & 5 & 1 & 3 & 7 & 32 & 5.7 \\
\hline Ortam, materyal, donanım & 2 & 14 & 2 & 20 & 1 & 5 & 1 & 4 & 6 & 43 & 7.6 \\
\hline Teknoloji & 3 & 17 & 3 & 21 & 5 & 34 & 1 & 13 & 12 & 85 & 15.0 \\
\hline Zaman & 1 & 3 & 1 & 3 & 1 & 4 & 1 & 4 & 4 & 14 & 2.5 \\
\hline Toplam & 19 & 142 & 15 & 116 & 17 & 238 & 8 & 70 & 59 & 566 & 100 \\
\hline$\%$ & & 25.1 & & 20.5 & & 42.0 & & 12.4 & & & \\
\hline
\end{tabular}

\section{Tartışma, Sonuç ve Öneriler}

Bu çalışmada, dijital çağın fırsatları dikkate alınarak yükseköğretim düzeyinde öğretimin nasıl daha etkili gerçekleştirilebileceği araştırılmıştır. Dokümanları incelemek için yönetim süreçleri ve öğretimsel ögelerin birleşimiyle oluşturulan bir matris kullanılmıştır. Böylece literatürde gömülü olan bulgular analitik yolla tasnif edilmiş ve tartışılarak hem uygulamaya hem de araştırmaya yönelik öneriler geliştirilmiştir. 
Bu çalışmada toplam 59 tema altında 566 bilgi parçası elde edilmiştir. Benzer bir çalışma yapan Hattie (2012) toplam 800 öğretimsel bilgi parçası elde etmiştir. Marzano (2007) ise 41 öğretimsel öge saptamıştır. İlki doküman analizi şeklinde gerçekleştirilmiş ve K-12 düzeyinde görsel öğrenmeye odaklanmıştır. Yükseköğretim düzeyinde henüz benzeri bir çalışmaya erişilmemekle birlikte Hattie (2012) tarafından gerçekleştirilen çalışmada saptanan öğretimsel ögelerin bu çalışmada elde edilenlerle benzerlik gösterdiği görülmüştür. Bu açıdan bir uyum olduğu söylenebilir.

Öğretimsel ögeler açısından bulgular sınıflandırılmıştır. Literatürde en sıklıkla model, strateji, yöntem ve teknik konuları ele alınmıştır $(f=208)$. Bu kapsamda kuram ve uygulama bağı kurma, dijital fırsatları dikkate alan pedagojik portföy oluşturma, proje-araştırma temelli ve gerçek hayatla bağlantılı teknikleri kullanma, çok yönlü bütüncül gelişime hizmet edebilecek ve öğrenci ihtiyaçlarını karşılayabilecek yöntemleri benimseme, biçimlendirici değerlendirmeyi kullanma, değerlendirmeden gelen bilgiyi öğretimi geliştirmek için kullanmakonuları öne çıkmaktadır. Yükseköğretim düzeyinde öğretim görevlilerinin alan bilgilerinin yanı sıra pedagojik portföy oluşturabilmeleri önemle vurgulanabilir. Öğretimöğrenme kuramları bilgisi ve bu bilgiyi uygulamaya aktarabilmek öğretimi etkili hale getirmekte başlangıç noktalarından birini oluşturmaktadir.

Felsefe, amaç ve hedefler ise 184 bilgi parçasını içermiş̧tir. Bu kısımda özellikle yeni ve kilit becerileri edindirme (yaratıcılık, girişimcilik, problem çözme, işbirliği yapma...), açık net hedefler ve müfredatın ötesine geçme, öğrencilerin beklenti, ihtiyaç ve fikirlerine önem verme, bütünsel gelişimi sağlama, öz-yeterlik duygusunu geliştirme, içsel motivasyonu destekleme, değerlendirme çeşitliliği sağlamakonuları dikkati çekmektedir.Mevcut uygulamalarda özellikle öğrenenlerin ihtiyaçlarını karşılayan hedefler, kazanımlar ve buna uygun içerik saptama sorunlu bir yön olarak saptanmaktadır (Doğanay ve Yeşilpınar-Uyar, 2019). Buna ek olarak öğretim görevlisi adaylarının öğretim-öğrenme kuramlarıyla alan bilgisi arasında bağ kurmaları ihtiyacı bildirilmektedir (Ünver, 2013).

Öğretimsel ögeler arasında en sık vurgulanan üçüncü öge ise teknolojidir. Dijital okur-yazarlık, tekno-pedagojik bilgi ve beceri, bireysel öğrenmeyi destekleme, yeni teknolojilerden (bulut, blockchain, yapay zeka, 
veri analizleri-raporlama, ürün oluşturma-sunma...) yararlanma, problem odaklı proje tabanlı ögretimde teknolojiden yararlanma, öğretimi zenginleştirmekonuları teknolojinin öğretime uygulanması kapsamında sıklıkla vurgulanmaktadır. Teknoloji destekli öğretimi gerçekleştirme eğitim reformlarının en sıklıkla vurgulanan öğretmen yeterlik yönlerinden biridir (OECD, 2017). Öğretmenlerin bu yöndeki yaratıcılıklarının desteklenmesi ve örnek uygulamaların paylaşılmasının önemi belirtilmektedir (Nitkin, 2018; Taylor ve MacKenney, 2008).

En az vurgulanan öğretimsel öge ise zamandır $(f=14)$. Bu kapsamda öğretimle geçirilen sürenin öğrenmeyle sonuçlanması, öğretim zamanı ve süresinin kaliteli olması, öğrenme süresi açısından bireysel farklılıkların dikkate alınması, görev-süre uyumu, değerlendirmenin sürekliliği konuları öne çıkmaktadır. Önceki çalışmalarda dersin zamanı bir sorun olarak bildirilmiştir (Doğanay ve Yeşilpınar-Uyar, 2019).Öğretimsel ögeler arasında öğrencilerin özellikleri de az vurgulanan konulardır oysa öğrenci özellikleri öğretimin etkililiği üzerinde oldukça önemli bir role sahiptir. Bu çalışmada öğrenci özellikleri kapsamında öğrencileri tanıma, öğrenciye göre pedagojik uygunluk sağlama, öğrenci ihtiyaç ve beklentilerini öğretimde dikkate alma, bireysel keşif ve paylaşımı geliştirme, başarıya ulaşmalarında destek sağlama konuları dikkati çekmektedir.

Elde edilen bulguların yönetim süreçlerine göre sinıflaması incelendiğinde özellikle planlama (\% 25.1), başlatma ve sürdürme (\% 42.0) süreçlerinin sıklıkla ele alındığı saptanmıştır. Planlama kapsamında en sıklıkla vurgulanan noktalar açık net hedefler belirleme, üst düzey becerilere odaklanma, uygulamayı geliştirme, gerçek hayatla bağ kurma, öğrencilerin bütüncül gelişimini sağlama, öğrenmeyi geliştirmede teknolojiyi dikkate alma, dijital okur-yazarlı̆̆ 1 geliştirme şeklinde sıralanabilir.Doğanay ve Yeşilpınar-Uyar (2019) tarafından gerçekleştirilen çalışmada ders planlamada, öğrenenlerin gerçek hayattaki ihtiyaçlarını karşılayabilen öğretimi tasarlamada sorunlar olduğu saptanmıştır.

Bulguların en yoğunlukla yer aldığ1 yönetim süreci uygulamadır. Bu süreç seçilen yöntemin öğrenmeyi etkilemesi, öğrenilenler arasında bağ kurulması, farklı teknikleri harmanlama, problem temelli ve proje bazlı etkinliklerin kullanılması, zenginleştirilmiş etkinlikler, dijital ortam ve araçlar kullanma, takımlar halinde çalışma, bilginin uygulamaya aktarılması, konular ve etkinlikler arasında aşamalılık sağlama, konuyu öğ- 
renilebilir kılma, tartışma, oyunlaştırma, soru-sorma, karşılaştırma, benzetim, çok değişkenli metaforlar kullanma, özetleme, anında dönüt, koçluk yapma, öğretimi bireysel farklılıklara uyarlama, davranışı izleyen teşvikler, başarıyı kutlamagibi eylemleri içine almaktadır. Uygulama sürecinde yer alan bilgi parçaları incelendiğinde en dikkat çekici ögelerin zenginleştirilmiş etkinliklerin kullanımı, etkinliklerin aşamalandırılarak ve uyum içinde gerçekleştirilmesi, öğrenci katılımı, etkinlikler sırasında öğrencilerin hatalarının tespit edilerek geliştirme aracı olarak kullanılması olduğu saptanmaktadır. Magana (2016) yaptığı çalışmada öğretim açısından en önemli işin "etkinlik tasarlama ve uygulama" olduğunu saptamıştır. Önceki çalışmalarda öğretimin etkili şekilde gerçekleştirilmesinde sorunlar olduğu, sınıf içi katılımın ve tartışmaların yeterli düzeyde olmadığı saptanmıştır (Doğanay ve Yeşilpınar-Uyar, 2019). Ayrıca öğretimin, öğrenmeyi sağlama yönünün zayıf olduğu belirlenmiştir (Ünver, 2013).

Yönetim süreçlerinden organizasyon kimin, neyi, ne ile ve nasıl yapacağını açıklama ve uygulamaya hazır hale getirmeyi ifade etmektedir. Bir başka söyleyişle yapıyı kurmaktır. Literatürde elde edilen bulgular organizasyon süreci açısından tasnif edilmiştir. Bu kapsamda elde edilen bilgi parçalarından bazıları öğrencilere yardım ve yönlendirme, hedefleri, kavramları açıklama, çeşitliliği dikkate alma, esneklik sergileme, bütünsel gelişime odaklanma, seçenekler sunma, farklı stratejiler arasında uyum sağlama, öğretim-öğrenme ve değerlendirme uyumunu gözetme, görevlendirmelerde bireysel farklılıkları dikkate alma, ortamı dönüştürebilme, teknolojik firsatları kullanma, dijital öğrenme araçlarını kullanma, öğrenme ile sonuçlanan öğretim süresini dikkate alma gibi sıralanmaktadır.

Bir diğer yönetim süreci ise denetimdir. Denetim, geliştirmeye yönelik içinde kontrol ve değerlendirmeyi de içine alan bir süreçtir (Başar, 2000). Bu süreç kapsamında saptanan bilgi parçaları farklı beceriler için farklı ölçme tekniklerinin kullanılması, veri temelli değerlendirme yapılması, öğretim-değerlendirme uyumunun sağlanması, biçimlendirici değerlendirme ve öğrenci öğrenmesini destekleme, ürünlerin değerlendirilmesi, değerlendirmede teknolojiyi kullanma, ekonomi ve kolaylık sağlama olarak özetlenebilir. Doğanay ve Yeşilpınar-Uyar, (2019) tarafından gerçekleştirilen çalışmada otantik değerlendirme vurgusu dikkati 
çekmektedir. Öğretim sürecindeki edinimlerin yalnızca çoktan seçmeli testlerle ölçülmeye çalışılması bir sorun olarak belirtilmektedir. Akademik başarıyı yalnızca belirli ölçme araçlarıyla ölçerek bu sonuçları çok önemli hale getirmek öğretim sürecini olumsuz etkileyebilmektedir (Magana, 2016).

Öğretimsel ögeler ve yönetim süreçleri birlikte değerlendirildiğinde felsefe, amaç ve hedeflerin özellikle planlama ve uygulama sürecinde yoğunlaştığı dikkati çekmektedir. Bu sonuç kuramsal çerçeveye uygundur çünkü felsefe, amaç ve hedefler geleceğe dönük ve eylemin nasıl olacağını biçimlendirdiğinden planlama ve uygulama aşamasında yoğunlaşması çalışmanın geçerliğini destekler yöndedir. Model, strateji, yöntem ve teknik ögesinin yönetim süreçleri arasından özellikle uygulama sürecinde yoğunlaştığı görülmektedir. Benzer şekilde teknoloji ögesi de uygulama sürecinde yoğunlaşmaktadır. Ortam, materyal ve donanım ögesi ise organizasyon sürecinde yoğunlaşmıştır. Organizasyon süreci planlama ve uygulama arasında yer alarak kimin neyi ne ile yapacağını belirtme (görevlendirme) işlevini gerçekleştirmektedir. Bu nedenle ortam, materyal ve donanım ögesinin organizasyon sürecinde yoğunlaşması gerçekliğe uygun görülebilir. Öğrenci özellikleri ise beklentiyle çelişmektedir çünkü uygulama süreci yerine planlama sürecinde yoğunlaşmaktadır. Zaman ögesi ise belirli bir süreçte yoğunlaşmamış; süreçlere dağılmıştır.

Dijital imkânların öğretime uygulanmasına ilişkin elde edilen bulgular farklı duyular harekete geçirme, bireysel farklılıklara duyarlı öğretim ve bilginin analizi ve raporlanmasında hız ve ekonomiklik sağlama şeklinde özetlenebilir. Takımlar halinde proje tabanlı öğretim yaklaşımının her aşamasında dijital fırsatlardan yararlanılabileceği görülmektedir. Ancak dijital çağın gerçek hayattaki yaygınlığı ve etkisine karşın öğretimsel açıdan bu yönü literatüre henüz yansımamıştır. Bu durum geleneksel öğretim uygulamalarının ağırlığını sürdürdüğü şeklinde yorumlanabileceği gibi öğretimi dönüştürme konusunda bilgi ve beceri eksikliğinin varlığına da işaret edebilir.

Literatüre dayalı elde edilen bulgular yönetim süreçleri dikkate alınarak aşamalandırılmıştır. Bu düzenleme ile 10 aşamadan oluşan öğretimin yönetimi basamakları saptanmıştır. Sorulara dönüştürülen her bir basamağı gerçekleştirme düzeyi öğretimin etkililiği hakkında öğretim görevlilerine değerlendirme fırsatı sağlayacaktır. Öğrencilerin neleri bilmesini 
ve neleri yapabilmesini istiyoruz? Öğrenciler bunlardan ne kadarına hangi düzeyde sahiptir? Öğrencilerin sahip olmasını hedeflediğimiz becerileri edinmelerini nasıl sağlayabiliriz? Öğretim görevlileri olarak bizler bunu sağlayabilecek bilgi, beceri ve diğer şartlara sahip miyiz? Öğrencilerin edinmesini istediğimiz bilgi ve becerileri kendi içinde nasıl aşamalandırabiliriz? Öğrencilerin hedeflenen bilgi ve becerileri edinmesini sağlayabilecek en etkili öğretim etkinlikleri neler olabilir? Bu etkinlikleri nasıl gerçekleştirebiliriz? Nasıl bir ortama, hangi materyallere ihtiyaç duyuyoruz? Etkinliklere katılım nasıl sağlanabilir? Hangi araçları ve donanımı sağlamalıyız? Kimin neyi nasıl ve neyle yapacağını açıkladık mı? Etkinlikler aracılığıyla öğrenciler neler edindiler? Hedeflediğimiz bilgi beceri ve tutumları edindiler mi? Öğrencilerin edinimlerini nasıl ölçebiliriz? Etkinliklerin tamamlanmasının ardından neler yapıldığ 1 hatırlandı mı? Neleri nasıl yapmıştık? Daha iyi yollar keşfedilebilir mi? Bir sonraki aşama için hazır mıyız? Biz öğretim görevlileri olarak öğretim sürecinde neler öğrendik? Bu öğretimin bize maliyeti ne oldu? Edinilenler ne ölçüde kaliteliydi?

Bu çalışmada saptananlar aracılığıyla, öğretim görevlileri kendi öğretim uygulamalarını öz-değerlendirmeye tabi tutabilirler. Ayrıca, sürekli eğitim merkezlerinde eğiticilerin eğitimi sırasında tanıtılabilir. Bu çalışmada işaret edilen problemli konulardan biri dijital fırsatların öğretimde kullanılmasındaki sınırlılıktır. Öğretim görevlilerinin bilgi ve beceri eksikliğinin bir sebep olarak dikkate alınması durumunda öğretim uygulamalarının çeşitlendirilebilmesi için öncelikle öğretim görevlilerinin dijital fırsatlar hakkında bilgilendirilmesi gereksinimi belirmektedir. Öğretim görevlilerinin öğretimi etkili şekilde gerçekleştirebilmeleri için yeterliklerinin artırılmasına yönelik eğitim ihtiyacı önceki çalışmalarda da vurgulanmaktadır (Doğanay ve Yeşilpınar-Uyar, 2019; Ünver, 2013). Bu çalışmada mevcut literatür temel alınarak yükseköğretimde öğretim betimlenmeye çalışılmıştır. Bulgular, olması gerekeni sunmaktadır. Fakat yükseköğretimde öğretimin nasıl olduğu hakkında çalışmalara ihtiyaç duyulmaktadır. Böylece, olması gereken ile mevcut karşılaştırılarak geliştirme yönünde müdahale noktaları saptanabilir. 


\section{EXTENDED ABSTRACT}

\section{Meta-analytic Analysis Concerning Instruction Management in Higher Education in Digital Age \\ Aydın Aslan - Kamil Yıldırım \\ Selçuk University - Aksaray University}

This study investigated how to implement more effective instruction in higher education considering the opportunities of the digital age. The main rationale behind this study is that any study concerning how to implement instruction in higher education in line with the characteristics of the digital age has not been reached. In this sense, there is a problem with respect to its implementation in education. Instruction management plays a crucial role in enhancing teaching and learning processes. Instruction management deals with not only planning, organizing, assignment, guidance, coordination, evaluation and reporting elements in management processes but also educational philosophy, aims and objectives, learners and their characteristics, physical environment, equipment and technology, teaching models, methods and techniques, and time period.

To determine the components of the instruction management, a metaanalytic analysis was conducted. For this purpose, "management process, instruction/teaching and digital" key words were searched in the search engines including Thomson-Reuters Web of Science, Academic Search Complete, ProQuest, OECD iLibrary, Ebook Central and Ulakbim Social Sciences Database in the past years. Following searching the key words in the search engines and a total of 195 documents published in books, theses and articles were got. Purposeful, stratified and random sampling was employed to select the documents. As a result of this sampling, 49 documents were chosen. The documents were numbered. The odd and even numbered ones were examined by the researchers separately. A matrix was created to examine the documents with regard to management processes consisting of planning, organization, implementation and controlling dimensions and six instructional elements. Content analysis was conducted to analyze the documents. The findings were 
analytically classified and 566 instructional elements under 59 themes were determined.

As a result of the study, it was found that the most frequently mentioned findings are implementation and model, strategy, method and technique instruction elements. In the implementation process, the most notified instructional elements are to use enriched activities and conduct these activities in a progressive order. It was also found that students' participation into activities are important and their mistakes should be used as means of development during these activities. In the context with the model, strategy, method and tecnique instruction elements, it appears that the most dealt issues include creating a pedagojic portfolio taking into account the digital opportunities, using project and research based techniques, embracing the methods meeting students' needs and using formative assessment. In this regard, it is emphasized that academic members should form their pedagic portfolio in addition to their content knowledge in higher education.

The findings derived from the literature review were staged with regard to management processes. Through this treatment, the instruction management consisting of 10 steps was identified. These steps were formed into the questions. To what extent these questions are fulfilled will enable academic members to evaluate their instructions' effectivity. To illustrate, what do we want our students to know and to do? To what extent do our student have the required knowledge? How can we enable our students to gain the objectives we have aimed? Do we have the necessary knowledge, skills and the other conditions to fulfill these objectives as academic members? What sort of circumstances, materials do we need? What sort of equipments and hardware should we provide for our students? What have the students learned by means of the activities conducted? Have they remembered what they did after the completion of the activities? Have they acquired the knowledge, skills and attitudes which we aimed? How can we evaluate their acquisitions? Are we ready for the next stage? What have we learned in the teaching process as academic members? In this way, academic members can make selfevaluation concerning their teaching practices through the feedbacks elicited from the posed questions. Another issue emphasized in this study is that the use of digital opportunities in the teaching and learning 
processes is limited. To integrate the digital opportunities in the educational practices, it seems vital for academic members to be informed about these opportunities. Besides, they need in-service training to increase their competences to effectively conduct teaching and learning processess.

In this study, the instruction in higher education was described based on the current literature. The findings present what has to be conducted in instruction. However, the studies dealing with how the instructions are implemented in higher education are needed. So, the instructions in higher education can be improved by making comparisons between the ideal and current situations in the implementations of instructions in higher education.

\section{Kaynakça / References}

Akpınar-Wilsing, N. ve Paykoç, F. (2004). Needs of future faculty members in relation to instructional planning, effective teaching and evaluation: A case study. Education \& Science, 29(133), 71-82.

Başar, H. (2000). Ĕ̆itim denetçisi. Ankara: PegemA.

Berner, H. (2013). Pedagojide güncel akımlar (Çev. Uludağ, Z., Uğursal, Ç., Bakır, N.). Ankara: Nobel Yayın.

Brown, G. ve Atkins, M. (1988). Effective teaching in higher education. London: Routledge.

Cangelosi, J.S. (2014). Classroom management strategies: Gaining and maintaining students' cooperation. Hoboken Nj: Wiley.

Çetinsaya, G. (2014). Büyüme, kaliteve uluslararasılaşma: Türkiye yükseköğretimi için bir yol haritasl[Growing, quality and internationalisation: a guide map for higher education in Turkey]. Ankara: YükseköğretimKuruluYayınları.

Drew, S. ve Klopper, C. (2014). Evaluating faculty pedagogic practices to inform strategic academic professional development: a case of cases. Higher Education 67: 349-367. DOI 10.1007/s10734-013-9657-1

Doğanay, A. veYeşilpınar-Uyar, M. (2019). Teaching competencies in higher education: A needs analysis study regarding to develop instructional planning and evaluation course. Inonu University Journal of theFaculty of Education, 20(1), 01-16. DOI: 10.17679/inuefd.299220 
Dumont, H., Istance, D. ve Benavides, F. (2010). The nature of learning: Using research to inspire practice. Paris: OECD Publication.

Eurydice (2016). Higher education governance in Europe: Policies, structures, funding and academic staff. 20.10.2016 tarihinde http://www.eurydice.org atadresinden erişildi.

Fidan, N. (2012). Okulda öğrenme ve öğretme. 3. Bask1.Ankara: PegemA

Fisher, N. (2007). 50 templates for improving teaching and learning.Cooksbridge UK: Connect.

Fraenkel, J.R., Wallen, N.E. ve Hyun, H.H. (2012). How to design and evaluate research in education. NY: McGraw-Hill.

Hattie, J. (2012). Visible learning for teachers: Maximizing impact on learning. New York: Routledge.

Hirsch, D. (2003). The management of learning, schools and systems. Schooling for tomorrow: Networks of innovation. Paris: OECD Publications.

Houston, D., Meyer, L. H. ve Paewai, S. (2006). Academic staff workloads and job satisfaction: Expectations and values in academe. Journal of Higher Education Policy and Management, 28(1), 17-30.

Hoy, K. W. ve Miskel, G. C. (2012). Eğitim yönetimi: teori, araştırma ve uygulama (S. Turan, Çev.). Ankara: Nobel Akademik Yayıncılık

UNESCO (2019). International standard classification of Education. 07.08.2019 tarihinde http://www.uis.unesco.org/Education/Pages/internationalstandard-classification-of-education.aspx adresinden erişildi.

Kavak, Y. (2011). Türkiye'de yükseköğretimde büyüme: Yakın geçmişe bakış ve uzunvadeli (2010-2050) büyüme projeksiyonları [Growth of higher education in Turkey: An overview to the last decade and long term (2010-2050) growth projections]. Journal of Higher Education, 1(2), 95-102. doi:10.2399/yod.11.095

Kerr, C. (2001). The uses of the university. Harvard University Press.

Kürüm, D. (2007). Öğretim üyesi adayları için öğretimsel gelişim programının değerlendirmesi. Yayımlanmamış doktora tezi, Anadolu Üniversitesi, Eskişehir, Türkiye.

Leibowitz, B., Bozalek, V., Schalkwyk, S. ve Winberg, C. (2015). Institutional context matters: the professional development of academics as teachers in South African higher education. Higher Education 69, 315330, DOI 10.1007/s10734-014-9777-2

Lunenburg, F.C. ve Ornstein, A.C. (2012). Educational Administration. Sixth edition. New York: Wadsworth. 
Mårtensson, K., Roxå, T. ve Olsson, T. (2011) Developing a quality culture through the Scholarship of Teaching and Learning, Higher Education Research \& Development, 30(1), 51-62, DOI: $10.1080 / 07294360.2011 .536972$

Magana, A.C. (2016). Enhancing the art and science of teaching with technology: A model for improving instructional quality for all students (Unpublished PhD Diss). Seattle University, USA.

Marzano, R. J. (2007). The art and science of teaching: A comprehensive framework for effective instruction. Alexandria, VA: Association for Supervision \& Curriculum Development.

Nitkin, D. (2018). Technology-based personalization: Instructional reform in five public schools. Unpublished doctoral dissertation, Columbia University, USA.

OECD. (2009). Higher education to 2030: Globalisation. Paris: OECD Publication.

OECD. (2008). Tertiary education for the knowledge society. Special features: Governance, funding, quality. Paris: OECD Publication.

OECD. (2016). Trends shaping Education. Paris: OECD Publication.

OECD. (2017). Education at a glance 2017. Paris: OECD Publishing.

Rogers, B. (2003). Effective supply teaching: Behaviour management, classroom discipline and colleague support.London: Sage.

Schleicher, A. (2016). Teaching excellence through Professional learning and policy reform: Lessons from around the World. Paris: OECD Publication.

Schunk, D. H. (2011). Öğrenme teorileri [Learning theories, 5. Basımdan çeviri]. Ankara: Nobel Yayın

Senemoğlu, N. (2009). Gelişim öğrenme ve öğretim kuramdan uygulama. Ankara: PegemA.

Stringer, E.T., Christensen, L.M. ve Baldwin, S.C. (2010). Integrating teaching, learning and action research: Enhancing instruction in the K-12 Classroom.London: Sage.

Taylor, G.R. ve MacKenney, L. (2008). Improving human learning in classroom: Theories and teaching practices.New York: Rowman \& Little field Education.

UNESCO. (2014). Education for All. Teaching and learning: Achieving quality for all. Paris: UNESCO Publication. 
Ünver, G. (2013). The effects of the educational training courses on the doctoral students' conceptions of effective teaching. Yükseköğretim Dergisi, 3(2), 82-89.

Vieluf, S., Kaplan, D., Klieme, E. ve Bayer, S. (2012). Teaching practices and pedagogical innovation: Evidence from TALIS. Paris: OECD Publication.

Wiseman, D.G. ve Hunt, G.H. (2014). Best practice in motivation and management in the classroom. Illinois: Charles $\mathrm{C}$. Thomas.

Yıldırım, K. ve Aslan, A. (2019). Instruction Management in Primary Education in Digital Era. In Bernd Vogler (Ed).,Teaching Practices: Implementation, Challenges and Outcomes (182 sayfa). USA: Nova Publishing.

YÖK. (2019). Yükseköğretim yeterlikler çerçevesi. 07.08. 2019 tarihinde https://uluslararasi.yok.gov.tr/uluslararasilasma/tyyc/tyyc-temelalan-ve-uygulamalari adresinden erişildi.

\section{Kaynakça Bilgisi / Citation Information}

Aslan, A. ve Yıldırım, K. (2020). Dijital çağda yükseköğretimde öğretimin yönetimine ilişkin meta-analitik bir çözümleme. OPUSUluslararası Toplum Araştırmaları Dergisi, 15(21), 505-534. DOI: 10.26466/opus. 627050 